isms of control of the biosynthesis of DNA. This was followed by a presentation by J.A. V. Butler (London), who described some experiments on the phosphorylation of thymidine by tissue extracts and on the incorporation of labelled thymidine into DNA. S. S. Cohen (University of Pennsylvania) discussed the changes in enzyme complement of bacteria infected with $T$-even bacteriophage, and referred in particular to the appearance of an active system which converts ribonucleotides to deoxyribonucleotides. Some recent work on the mechanism of replication of bacteriophage $\varphi X 174$ were described by $R$. L. Sinsheimer (Pasadena), from which it seems that on infection a replicative form of DNA is produced which has characteristics of a double-stranded DNA.

The fifth and sixth sessions dealt with "Induced Changes in DNA". R. Litman (University of Colorado) discussed the effects of ultra-violet irradiation and nitrous acid on pneumococcal-transforming DNA, and the chemical and biological effects of nitrous acid and hydroxylamine on DNA from tobacco mosaic virus and $T$-even bacteriophages were described by H. Schuster and W. Vielmetter (Tubingen). P. D. Lawley (London) reported on the effects of alkylating agents on DNA. The relative reactivities of the different bases in DNA were described and the possibilitios of cross-linking in the DNA molecule were discussed. Experiments directed towards elucidating the mechanism of action of succinic peroxide on DNA by chemical, physico chemical and biological procedures were discussed by D. Luzzati (Strasbourg). G. Stent (Berkeley) discussed the susceptibility to mutagenesis by 5-bromodeexyuridine and the stabilization to phosphorus-32 decayinactivation of $T 4$ bacteriophage-infected bacteria. D. Shugar (Warsaw) was unable to attend the meeting, but submitted an abstract dealing with the primary effects of ultra-violet radiation on nucleic acids; these include hydration and dimerization of pyrimidine residues. An additional paper on the dimerization of thymine by ultra-violet radiations was presented by W. Berends (Pays Bas). R. Latarjet (Paris) described recent investigations on the action of $\mathrm{X}$-rays on pyrimidine bases in aqueous solution with the formation of hydroperoxides, and some work on the lethal effects of radioactive decay in bacteria after labelling of the DNA in different sites with phosphorus-32, carbon-14 and tritium. W. Harm (Cologne) discussed the reactivation of bacteriophage following inactivation by exposure to ultra-violet light and divided the reactions into two principal classes, namely, 'recombinative reactivation' and 'true repair mechanisms'.

The seventh session was concerned with "Code and Replication". A. Garen (Philadelphia) described alterations in alkaline phosphatase resulting from mutations, and J. Weigle and F. Stahl (Pasadena) discussed chromosome breakage and genetic recombination in bacteriophage $\lambda$ and the role of duplication in recombination.

"Genetic Aspects" provided the subject of the finel session of the symposium. L. Grossman (Brandeis University) presented some work on the chemistry and antigenecity of DNA from $T 2, T 4$ and $T 6$ bacteriophage. Thermally denatured DNA from these bacteriophages will react with antibodies in the antisera of rabbits immunized with the respective ruptured bacteriophage, but native or renatured DNA shows little reactivity. H. Ephrussi-Taylor (Paris) described a study of recombination at the molecular level in bacterial transformations and F. Jacob and F. Gros (Paris) discussed the regulation and mode of action of genes. The role of messenger RNA in these reactions was also discussed. The final paper of the session was delivered by $R$. Herriott (Baltimore), who described experiments on the annealing of mixtures of transforming DNAs.

The timing of the meeting was such as to allow for plenty of discussion during each session, and advantage was taken of this by many of the participants with the result that lively and valuable discussions followed most of the presentations. In every respect this was a highly successful meeting and the organizing committee of the Société de Chimie Physique is to be congratulated on the arrangements.

R. M. S. SMELLIE

\title{
QUANTITATIVE BIOLOGY
}

A $\mathrm{N}$ informal symposium on "Quantitative Biology", at which sixty biochemists, biophysicists and biologists met to discuss their common problems, was held at the Dominion Physical Laboratory, Lower Hutt, New Zealand, on May 12. The meeting was arrangod by the biophysicists, who felt that New Zealand workers in these fields had insufficient opportunity to get together. The enthusiastic response and the success of the meeting showed how general this feeling must have been.

In the morning session of the symposium the hosts introduced their own work. Dr. M. C. Probine, who is measuring the physical properties of the primary wall of plant cells, showed how changes in the shape of growing Nitella cells could be predicted from the initial orientation of the reinforcing microfibrils and the elastic and plastic properties of the wall. Dr. K. J. McCree discussed his programme for measuring the photoconductivity of oriented monolayers of organic materials, produced by the Langmuir technique. Mr. M. A. Collins described his electronspin-resonance spectrometer, and demonstrated the signals of free radicals occurring naturally in coal and those produced by the $\gamma$-irradiation of cellulose. The spectrometer will also be used to study the physics of photosynthesis, in conjunction with the photoconductivity experiments.

Some striking electron micrographs of the wax on the surfaces of clover leaves were exhibited by Mr. D. M. Hall. They showed how the pattern varied with the species of clover, and how the wax could be removed by the rubbing together of leaves in a high wind. Mr. W. S. Bertraud described the changes in the components of the spermatid cells of the cave weta (Pachyrhamma fascifer) which took place during spermiogenesis.

In the afternoon, Dr. E. G. Bollard, of the Fruit Research Division, Department of Scientific and Industrial Research, described the utilization of various organic nitrogen compounds as sole sources of nitrogen, in the sterile culture of Neurospora, Chlorella, Spirodela and carrot root tissue. He was followed by Dr. R. E. F. Matthews, of the Plant Diseases Division, who had found (working with 
Dr. R. I. B. Francki) that the uracil analogue 2-thiouracil had very different effects on the rod-shaped tobacco mosaic virus and on the spherical turnip yellow mosaic virus. After tea, Dr. G. A. Nicholls, of New Zealand Forest Products, Ltd., took his audience on an illustrated tour of his firm's plant, and discussed the work of his laboratory in the fields of bark utilization, pulping, bleaching and turpentine refining. Dr. A. T. Wilson, of Victoria University of Wellington, then wound up the proceedings with a highly entertaining exposition of his theories on the physical system in which life may have originated.
In the discussion of the way in which future meetings should be organized, there was general agreement that they should be kept as informal as possible, so that ideas could be aired and discussed before they had reached the stage of publication. It was also agreed that the meetings should be held at various laboratories in turn, so that in time everyone would have a first-hand knowledge of what everyone else was doing. Of the various time-intervals which were suggested, a year was most favoured, and Drs. McCree and Probine were asked to handle the arrangements for the next meeting. K. J. MCCREE

\section{MEDICAL RESEARCH IN THE BRITISH CARIBBEAN}

$\mathrm{T}$ HE sixth scientific meeting of the Standing Advisory Committee for Medical Research in the British Caribbean was held at the Marine Hotel, Bridgetown, Barbados, during April 10-13. Thirtyeight communications were delivered, and six were read by title only. Chairmen for the five sessions were Sir Harold Himsworth, Prof. T. H. Weller, Prof. A. C. Frazer, Dr. E. T. C. Spooner and Prof. E. K. Cruickshank.

The meeting was remarkable for the high standard of presentation, the diversity of subject-matter, and for the evidence which it offered of the stimulating effect of a research interest on all fields of medicine and its ancillary professions. The theme of the meeting-the impact of research on public healthwas chosen to be as nearly all-embracing as possible.

R. A. Irvine, C. Miller and L. S. Grant (Univ. Coll., West Indies) reviewed typhoid infection in Jamaica. During the period 1952-59, typhoid fever had affected chiefly the younger age groups, with a relapse-rate of 8 per cent and a case fatality of 5.8 per cent. M. T. Ashcroft (British Guiana) reported a steady decline in fatality of typhoid fever in British Guiana, partly due to improved water supply and partly to the introduction of chloramphenicol treatment. C. C. Nicholson and J. M. Ritchie (British Guiana) directed attention to imperfections still remaining in British Guiana water supplies. E. H. Back and S. E. Brooks (Univ. Coll., West Indies) analysed 134 cases of gastroenteritis in infants admitted to University College Hospital, Jamaica, and discussed prognosis. F. C. Ramsey (Barbados) described scarlet fever in Barbados, suggesting that the disease is less rare than it is said to have been. G. Bras, D. Watler and S. E. Brooks (Univ. Coll., West Indies) quoted figures from the Cancer Registry at University College Hospital to show that carcinoma of the cervix in Jamaica is responsible for more than 30 per cent of all malignancy in females. J. D. Arneaud (Trinidad) discussed drug resistance of tubercle bacilli isolated in Trinidad. K. D. B. Charles (Jamaica) and L. S. Grant (Univ. Coll., West Indies) reviewed poliomyelitis in Jamaica with special reference to the epidemics of 1954, 1957 and 1960. J. S. R. Golding (Univ. Coll., West Indies) described the management of those disabled. in a moderately severe epidemic of poliomyelitis, and demonstrated the necessity for a planned programme. L. Spence (Trinidad) gave an account of the distribution of Eastern equine encephalitis virus in Trinidad and British Guiana. In Trinidad, the virus has been isolated on six occasions from culicine mosquitoes; and in British Guiana from horses during an outbreak. In Trinidad, immunity has been demonstrated in humans, birds and poultry. L. S. Grant (Univ. Coll., West Indies) reported a survey of $Q$ fever antibodies in Jamaica, showing that this infection is not at present prevalent. W. G. Downs, L. H. Turner and A. E. Green (Trinidad) found 10 per cent of human sera from cases of undiagnosed fever in Trinidad agglutinated leptospiræ, and reported 17 isolations of leptospirze in culture. They directed attention to the lack of knowledge of the local ecology of leptospirosis. A. V. Wells (St. Lucia) described the successful eradication of malaria from St. Lucia. G. Giglioli (British Guiana) discussed the effect of malaria eradication in British Guiana on mortality from chronic nephritis. F. R. S. Kellett (Trinidad), as part of the malaria eradication plan in Trinidad, had used 'Baytex' (S 29493) as a spray, and showed that this insecticide is effective on various household pests including culicine mosquitoes. T. H. G. Aitken (Trinidad) discussed the ecology of Culex quinquefasciatus and its importance for public health in the Caribbean area as a vector of filaria, St. Louis encephalitis and Cache Valley fever. L. M. Burke (Jamaica) gave an account of the clinical features of poliomyelitis in Jamaica, as seen in a study of 309 cases admitted to Kingston Public Hospital during 1957-60. J. A. S. Hall (Jamaica) discussed the role of infection in a series of twenty cases of myelomatosis. E. H. Back and E. E. DePass (Univ. Coll., West Indies) considered rheumatic fever as seen in University College Hospital, Jamaica, during 1952-60, and described the beneficial effect of maintenance benzathine penicillin. F. M. McWatt (British Guiana) read an interesting paper on liver cirrhosis in cattle on the savannahs of British Guiana, where three species of Crotalaria have been identified. The cause of the disease has not been ascertained, but liver biopsies have shown that the fibrosis regresses at certain times of year or when the animals are moved to improved pastures. E. E. Ward and E. H. Back (Univ. Coll., West Indies) reported work on electrolyte disturbance in infantile gastroenteritis. T. Poon-King (Trinidad) gave an important account of electrocardiographic changes observed in patients stung by the Trinidad scorpion, Tityus trinitatis. The sting of this scorpion produces severe physiological disturbance and sometimes kills. Electrocardiographic abnormalities were found in 39 of 45 patients studied. E. E. Ward (Univ. Coll., West Indies) 